\title{
Evaluation of F-Measure and Feature Analysis of C5.0 Implementation on Single Nucleotide Polymorphism Calling
}

\author{
${ }^{1}$ Lailan Sahrina Hasibuan, ${ }^{2}$ Sita Nabila, ${ }^{3}$ Nurul Hudachair, ${ }^{4}$ Muhammad Abrar Istiadi \\ ${ }_{1,2,3,4}$ Department of Computer Sciences, Faculty of Mathematics and Natural Sciences, Bogor Agricultural University \\ ${ }^{1,4}$ Bioinformatics Working Group, Faculty of Mathematics and Natural Sciences, Bogor Agricultural University \\ Email: ${ }^{1}$ lailan.sahrina@apps.ipb.ac.id, ${ }^{2}$ nabila@apps.ipb.ac.id, ${ }^{3}$ nurul_hudachair@apps.ipb.ac.id, ${ }^{4}$ abrari@apps.ipb.ac.id
}

\begin{tabular}{l}
\hline Article Info \\
\hline Article history: \\
Received Feb 4 $4^{\text {th }}, 2018$ \\
Revised Feb $17^{\text {th }}, 2018$ \\
Accepted Mar $5^{\text {th }}, 2018$
\end{tabular}

\section{Keywords:}

Analisis fitur

C5.0

Decision tree

NGS

SNP calling

\begin{abstract}
Data growing in molecular biology has increased rapidly since NextGeneration Sequencing (NGS) technology introduced in 2000, the latest technology used to sequence DNA with high throughput. Single Nucleotide Polymorphism (SNP) is a marker based on DNA which can be used to identify organism specifically. SNPs are usually exploited for optimizing parents selection in producing high-quality seed for plant breeding. This paper discusses SNP calling underlying NGS data of cultivated soybean (Glycine max [L]. Merr) using C5.0, an improved rule-based algorithm of C4.5. The evaluation illustrated that C5.0 is better than the other rule-based algorithm CART based on f-measure. The value of f-measure using C5.0 and CART are 0.63 and 0.58 . Besides of that, C5.0 is robust for imbalanced training dataset up to $1: 17$ but it is suffer in large training dataset. C5.0's performance may be increased by applying bagging or the other ensemble technique as improvement of CART by applying bagging in final decision. The other important thing is using appropriate features in representing SNP candidates. Based on information gain of C5.0, this paper recommends error probability, homopolymer left, mismatch alt and mean nearby qual as features for SNP calling.
\end{abstract}

Copyright $@ 2018$ Puzzle Research of Data Technology

\section{Corresponding Author: \\ Lailan Sahrina Hasibuan \\ Department of Computer Sciences \\ Faculty of Mathematics and Natural Sciences \\ Bogor Agricultural University \\ Meranti Wing 20 Level 5, Bogor Indonesia \\ Email: lailan.sahrina@apps.ipb.ac.id}

\section{PENDAHULUAN}

Pertumbuhan data di bidang biologi molekuler mengalami peningkatan yang signifikan dalam dua dekade terakhir, terutama sejak teknologi Next-Generation Sequencer (NGS) diperkenalkan pada tahun 2000 [1]. NGS merupakan teknologi sequencing Deoxyribo Nucleic Acid (DNA) yang dilakukan secara paralel dan masif sehingga mampu menghasilkan data sekuen dengan ukuran gigabyte dalam waktu beberapa hari, suatu pekerjaan yang sebelumnya membutuhkan waktu belasan tahun [2]. DNA manusia yang memiliki panjang 3 megabase pairs (mbs) dapat dibaca dalam waktu 2 minggu menggunakan teknologi NGS, sementara sebelumnya membutuhkan waktu 15 tahun untuk menyelesaikannya.

Data sekuen DNA sangat bermanfaat untuk mempelajari sistem kehidupan seperti: pewarisan sifat dari satu generasi ke generasi berikutnya, kerentanan suatu makhluk hidup terhadap penyakit yang belum diketahui ciri-cirinya dan perancangan personalized medicine [3]. Dalam bidang pertanian, data ini umumnya dimanfaatkan untuk menentukan penanda fenotipe pada level genomik. Penggunaan penanda ini dapat menghemat waktu pada proses seleksi tanaman untuk menghasilkan bibit unggul [4] [5].

Pada saat ini, penanda pada level genomik yang umum digunakan adalah Single Nucleotide Polymorphism (SNP). SNP dapat diartikan sebagai variasi basa nukleotida pada posisi yang sama di antara fragmen-fragmen DNA yang dijajarkan. Fragmen-fragmen DNA tersebut berasal dari individu yang berbeda pada populasi yang sama. Penanda SNP menjadi umum digunakan karena jumlahnya yang cenderung banyak dibandingkan penanda lainnya seperti Simple Sequence Repeat (SSR), Random-Amplified Polymorphic DNA 
(RAPD), Amplified Fragment Length Polymorphism (AFLP) [6]. Oleh karena itu, identifikasi SNP merupakan penelitian yang memiliki peran strategis dalam bidang bioinformatika. Identifikasi SNP umumnya disebut SNP calling atau variant calling. Pada penelitian ini, istilah yang digunakan untuk menyatakan identifikasi SNP adalah SNP calling.

Berbagai penelitian mengenai SNP calling telah dilakukan sebelumnya. Pada tahun 2013, O'Fallon et. al. melakukan SNP calling menggunakan Support Vector Machine (SVM) dengan Radial Basis Function (RBF) sebagai kernel pada data exome wanita Kaukasian di Eropa Timur. Evaluasi berdasarkan sensitivity adalah 87.5\% [7]. Pada tahun 2014, Hasibuan et. al. melakukan SNP calling menggunakan SVM dan RBF sebagai kernel dengan fokus masalah pada ketidakseimbangan data. Data yang digunakan adalah wholegenome dari Glycine max [L.] Merr sebanyak 1\% dari kromosom 16. Hasil penelitian ini menunjukkan bahwa penerapan undersampling mampu meningkatkan $f$-measure hingga $50 \%$, yaitu $57 \%$ menjadi $89 \%$ [8].

Kedua penelitian sebelumnya menggunakan pendekatan black box sehingga, proses SNP calling bersifat kabur. Pada tahun 2017, Hasibuan et. al. menggunakan pendekatan rule-based classification and regression trees (CART) untuk proses SNP calling pada data whole-genome dari Glycine max [L.] Merr. kromosom 16 [9]. Evaluasi model berdasarkan f-measure adalah $57 \%$. Penelitian ini berhasil mengidentifikasi 4 buah fitur yang dominan dari 24 fitur yang digunakan, yaitu: kualitas maksimum alel minor, frekuensi alel minor, total alel varian dan total alel referen.

Berdasarkan data empris dari penelitian Loh pada tahun 2011, C4.5 memiliki akurasi yang lebih tinggi dibandingkan CART dalam mengidentifikasi jenis kendaraan [10]. Algoritme C5.0 adalah pengembangan dari $\mathrm{C} 4.5$, salah satunya dari sisi pruning [11]. Oleh karena itu, penelitian ini melakukan SNP calling pada data whole-genome dari Glycine max [L.] Merr. menggunakan pendekatan rule-based C5.0 untuk menganalisis pengaruhnya terhadap $f$-measure dan menganalisis fitur-fitur dominan yang berperan dalam proses SNP calling.

\section{DATA DAN METODE}

\subsection{Data}

Data yang digunakan pada penelitian ini adalah data fragmen DNA kedelai budidaya (Glycine max [L.] Merr.) hasil penelitian Lam et al pada tahun 2010 [11]. Praproses data telah dilakukan oleh [8] dan [12] . Tahap praproses data yang dilakukan meliputi: uji kualitas terhadap fragmen-fragmen DNA, penjajaran terhadap genom rujukan, pengelompokan berdasarkan kromosom, penentuan kandidat SNP dan ekstraksi 24 fitur kandidat SNP. Kelas kandidat SNP terdiri atas 2 yaitu: positif dan negatif. SNP positif berarti variasi basa karena adanya polymophism. SNP negatif berarti variasi basa palsu, yaitu kemunculan variasi yang disebabkan adanya kesalahan pada proses-proses sebelumnya.

\subsection{Pelatihan dan Pengujian}

Glycine max [L.] Merr. memiliki 20 kromosom yang dikode dengan Gm01-Gm20. Kandidat SNP yang paling banyak terdapat pada Gm18, sementara kandidat SNP yang paling sedikit terdapat pada Gm16. Tabel 1 menunjukkan jumlah kandidat SNP pada kromosom yang digunakan pada penelitian ini. Pada tahap awal, penelitian ini menggunakan 2 kromosom terpendek yaitu Gm11 dan Gm16 untuk pelatihan dan pengujian model C5.0. Setelah proses pelatihan dan pengujian, analisis fitur dilakukan untuk mencari fitur yang memiliki peran paling dominan dalam proses SNP calling. Analisis dilakukan berdasarkan information gain setiap fitur. Semakin besar nilai information gain, semakin besar nilai dominansi fitur tersebut. Menurut [13] nilai information gain suatu fitur $F$ yang memiliki 2 kemungkinan nilai $v_{1}$ dan $v_{2}$ dapat dihitung menggunakan Persamaan 1.

$$
\operatorname{Gain}(S, F)=H(S)-\frac{S_{v_{1}}}{S} H\left(S_{v_{1}}\right)-\frac{S_{v_{2}}}{S} H\left(S_{v_{2}}\right)
$$

Dengan $S_{v_{1}}$ adalah jumlah kandidat SNP yang memiliki nilai $v_{1}$ untuk fitur $F$, dan $S_{v_{2}}$ adalah jumlah kandidat SNP yang memiliki nilai $v_{2}$ untuk fitur $F$. Selanjutnya, $H(S)$ adalah nilai entrophy. Jika $S$ adalah jumlah kandidat SNP yang terdiri atas SNP positif $\mathrm{S}^{+}$dan SNP negatif $\mathrm{S}^{-}$, maka $H(S)$ dapat dihitung menggunakan Persamaan 2.

$$
H(S)=-\frac{S^{+}}{S} \log _{2} \frac{S^{+}}{S}-\frac{S^{-}}{S} \log _{2} \frac{S^{-}}{S}
$$

Pada tahap selanjutnya, metode yang sama diterapkan pada 2 kromosom yang paling panjang yaitu Gm18 dan Gm01. Hal ini dilakukan untuk menjawab pertanyaan "Apakah fitur-fitur yang dominan pada kromosom Gm11 memiliki dominansi yang sama pada kromosom lainnya?" 
Tabel 1. Jumlah kandidat SNP pada kromosom yang diteliti

\begin{tabular}{lrrcr}
\hline Kromosom & SNP positif & SNP negatif & Perbandingan & Total SNP \\
\hline Gm16 & 154817 & 1369758 & $1: 8$ & 1524576 \\
Gm11 & 87508 & 1566161 & $1: 17$ & 1653670 \\
Gm01 & 138368 & 2216578 & $1: 16$ & 2354946 \\
Gm18 & 233097 & 2377348 & $1: 10$ & 2610445 \\
\hline
\end{tabular}

\subsection{Evaluasi}

Performa algoritme C5.0 dalam melakukan SNP calling dievaluasi menggunakan matriks konfusi yang terdiri atas: true positive (TP), false positive (FP), false negative ( $\mathrm{FN}$ ) dan true negative (TN). Berdasarkan matriks konfusi, dapat diturunkan beberapa metrik evaluasi lainnya yaitu: akurasi, sensitifity/recall/true positive rate (TPR), specificity, precision dan f-measure [14] [15]. Pada penelitian ini, $f$ measure digunakan sebagai metrik evaluasi akhir karena adanya ketidakseimbangan data yang signifikan antara kelas SNP positif dan SNP negatif seperti yang tertera pada Tabel 1. Persamaan $f$-measure menurut [16] tersaji pada Persamaan 3.

$$
f-\text { measure }=\frac{2 * \text { precision } * \text { recall }}{\text { precision }+ \text { recall }}
$$

\section{HASIL DAN PEMBAHASAN}

Performa model C5.0 dalam melakukan SNP calling disajikan pada Tabel 2. Data pada tabel tersebut menunjukkan bahwa performa C5.0 lebih baik dibandingkan CART berdsarkan $f$-measure, yaitu 0.63 dan 0.58 . Nilai $f$-measure 0.63 dibentuk dari nilai recall 0.60 yang memiliki arti bahwa setiap kandidat SNP kelas positif memiliki peluang 60\% teridentifikasi sebagai SNP positif dan nilai precision 0.67 yang memiliki arti bahwa SNP calling yang dilakukan memiliki peluang $67 \%$ benar. Jika dibandingkan dengan metode CART yang dilengkapi teknik bagging pada keputusan akhirnya, ternyata performa C5.0 mampu menyamainya berdasarkan metrik $f$-measure, yaitu 0.63 .

SNP calling merupakan kasus binary classification dengan data tidak seimbang. Ketidakseimbangan data SNP positif dan SNP negatif tersaji pada Tabel 1. Ketidakseimbangan yang paling tinggi terjadi pada Gm11. Pada dataset ini, SNP positif hanya diwakili 5\% dari total data. Menurut [17], pelatihan model menggunakan data tidak seimbang akan menghasilkan model yang bias karena cenderung terhadap kelas mayor, yaitu SNP negatif.

Berdasarkan data yang disajikan pada Tabel 2, f-measure model yang dilatih menggunakan data dengan ketidakseimbangan yang tinggi, yaitu Gm11, dapat mengungguli f-measure model Gm18 dengan ketidakseimbangan yang lebih rendah. Hal ini menunjukkan bahwa C5.0 robust terhadap data tidak seimbang. Namun, C5.0 tidak robust terhadap ukuran data uji. Ukuran data uji yang besar dapat menurunkan nilai f-measure. Hal ini terlihat dari penurunan nilai f-measure sebesar 4\% (0.03) antara model Gm11 yang diuji oleh Gm16 dan model Gm18 yang diuji oleh Gm01.

Pada penelitian sebelumnya [9], penerapan bagging untuk algoritme CART dapat meningkatkan $f$ measure model sebanyak 8\% (0.05). Hal yang sama dapat terjadi pada algoritme C5.0, penggunaan bagging ataupun teknik ensemble lainnya memiliki peluang meningkatkan metrik $f$-measure.

Tabel 2. Evaluasi performa model dalam SNP calling

\begin{tabular}{cclrrr}
\hline \multicolumn{2}{c}{ Dataset } & \multirow{2}{*}{ Model } & Recall & \multirow{2}{*}{ Precision } & f-measure \\
\hline Data Latih & Data Uji & & 0.60 & 0.67 & $\mathbf{0 . 6 3}$ \\
& Gm16 & C5.0 & 0.51 & 0.67 & $\mathbf{0 . 5 8}$ \\
& & CART $^{*}$ & 0.6 & 0.66 & $\mathbf{0 . 6 3}$ \\
& & Bagging CART & & \\
Gm18 & Gm01 & C5.0 & 0.56 & 0.64 & $\mathbf{0 . 6 0}$ \\
\hline
\end{tabular}

*Hasil berdasarkan penelitian [9]

Performa model dalam melakukan SNP calling, selain dipengaruhi oleh model atau algoritme yang digunakan, juga dipengaruhi oleh fitur yang digunakan untuk merepresentasikan setiap variasi basa. Dengan kata lain, penggunaan fitur yang tepat dapat meningkatkan performa model [19]. Berdasarkan information gain, dua fitur yang paling berpengaruh pada pelatihan model menggunakan Gm11 adalah error probability dan homopolymer left. Sementara itu, dua fitur yang paling berpengaruh pada pelatihan model menggunakan Gm18 adalah mismatch alt dan mean nearby qual.

Dengan asumsi bahwa fragmen-fragmen yang mengandung kandidat SNP memiliki distribusi binomial, berikut ini dijelaskan pengertian dari fitur-fitur yang dianggap dominan. Error probability menyatakan peluang kandidat SNP adalah homozigot, heterozigot dan error [7]. Homopolymer left 
menyatakan banyaknya homopolimer genom rujukan pada bagian kiri kandidat SNP [7]. Mismatch alt menyatakan jumlah kandidat SNP pada fragmen yang mengandung kandidat SNP [7]. Mean nearby qual menyatakan rata-rata kualitas basa yang mengapit posisi kandidat SNP [7].

\section{KESIMPULAN}

Berdarkan hasil yang diperoleh pada penelitian ini, terdapat beberapa kesimpulan yang disajikan sebagai berikut:

(1) Secara empiris, C5.0 dan bagging CART memiliki performa yang sama dalam melakukan SNP calling. Oleh karena itu, penggunan bagging atau teknik ensemble lainnya memiliki peluang meningkatkan performa C5.0.

(2) Secara empiris, C5.0 robust terhadap data tidak seimbang namun tidak robus terhadap ukuran data uji yang besar.

(3) Berdasarkan information gain, penelitian ini merekomendasikan penggunaan fitur error probability, homopolymer left, mismatch alt dan mean nearby qual untuk melakukan SNP calling.

\section{UCAPAN TERIMA KASIH}

Penulis mengucapkan terima kasih kepada ticntech yang telah menyediakan server untuk mengolah data pada penelitian ini

\section{REFERENSI}

[1] M. Barba, H. Czosnek, and A. Hadidi, "Historical Perspective, Development and Applications of NextGeneration Sequencing in Plant Virology," viruses, vol. 6, n 2014, pp. 106-136, 2014.

[2] M. Gu'vic, "The History of DNA Sequencing," J Med Biochem, vol. 32, n 2013, pp. 301-312, 2013.

[3] W. Kong, and K. W. Choo, "Predicting Single Nucleotide Polymorphisms (SNP) from DNA sequence by Support Vector Machine," Frontiers in Bioscience, vol. 12, nº 2007, pp. 1610-1614, 2007.

[4] J. Mammadov, R. Aggarwal, R. Buyyarapu, and S. Kumpatla, "SNP Markers and Their Impact on Plant Breeding," International Journal of Plant Genomics, vol. 2012, 2012.

[5] N. M. Boopathi, "Marker-Assisted Selection," em Genetic Mapping and Marker Assisted Selection, Springer India, 2013, pp. 173-186.

[6] L. K. Matukumalli, J. J. Grefenstette, D. L. Hyten, I. Y. Choi, P. B. Cregan, and C. P. V. Tassell, "Application of machine learning in SNP discovery," BMC Bioinformatics, vol. 7, nº 4, 2006.

[7] B. D. O'Fallon, W. W. Donahue, and D. K. Crockett, "A support vector machine for identification of single-nucleotide polymorphisms from next-generation sequencing data," Bioinformatics, vol. 29, $\mathrm{n}^{\circ}$ 11, p. 1361-1366, 2013.

[8] L. S. Hasibuan, W. A. Kusuma, and W. B. Suwarno, "Identification of single nucleotide polymorphism using support vector machine on imbalanced data," em International Conference on Advanced Computer Science and Information Systems (ICACSIS), Jakarta, 2014.

[9] L. S. Hasbuan, N. Hudachair, and M. A. Istiadi, "Bootstrap Aggregating of Classification and Regression Trees in Identification of Single Nucleotide Polymorphisms," em International Conference on Advanced Computer Science and Information Systems (ICACSIS), Jakarta, 2017.

[10] W. Y. Loh, "Classification and regression trees," Wiley Interdisciplinary Reviews: Data Mining and Knowledge Discovery, vol. 1, pp. 14-23, 2011.

[11] R. Pandya, and J. Pandya, "C5.0 Algorithm to Improved Decision Tree with Feature Selection and Reduced Error Pruning," International Journal of Computer Applications, vol. 117, n 16, pp. 18-21, 2015.

[12] H.-M. Lam, X. Xu, X. Liu, W. Chen, G. Yang, F.-L. Wong, M.-W. Li, W. He, N. Qin, B. Wang, and J. $\mathrm{Li}$, "Resequencing of 31 wild and cultivated soybean genomes identifies patterns of genetic diversity and selection," Nature Genetics, vol. 42, n 12, p. 1053-1059, 2010.

[13] M. A. Istiadi, W. A. Kusuma, and I. M. Tasma, "Application of Decision Tree Classifier for Single Nucleotide Polymorphism Discovery from Next-Generation Sequencing Data," em International Conference on Advanced Computer Science and Information Systems (ICACSIS), Jakarta, 2014.

[14] J. Han, M. Kamber, and J. Pei, Data mining: concepts and techniques, Elsevier, 2011.

[15] H. He, and E. A. Garcia, "Learning from imbalanced data," IEEE Transactions on knowledge and data engineering, vol. 21, $\mathrm{n}^{\circ}$ 9, pp. 1263-1284, 2009.

[16] X.-Y. Liu, J. Wu, and Z.-H. Zhou, "Exploratory undersampling for class-imbalance learning," IEEE 
Transactions on Systems, Man, and Cybernetics, Part B (Cybernetics), vol. 39, n 2, pp. 539-550, 2009.

[17] S.-J. Yen, and Y.-S. Lee, "Cluster-based under-sampling approaches for imbalanced data distributions," Expert Systems with Applications, vol. 36, n 3, pp. 5718-5727, 2009.

[18] Cieslak, A. David, and V. Nitesh, "Learning decision trees for unbalanced data," em Joint European Conference on Machine Learning and Knowledge Discovery in Databases, 2008.

[19] U. Ojha, M. Jain, G. Jain, and R. K. Tiwari, "Significance of Important Attributes for Decision Making Using C5.0," em International Conference on Computing, Communication and Networking Technologies (ICCCNT), New Delhi, 2017.

\section{BIBLIOGRAFI PENULIS}

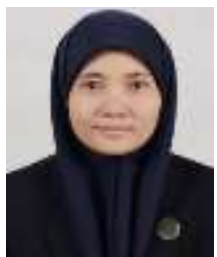

Penulis adalah pengajar di Departemen Ilmu Komputer Institut Pertanian Bogor (IPB). Selain itu, penulis juga bergabung di Bioinformatics Working Group, FMIPA IPB

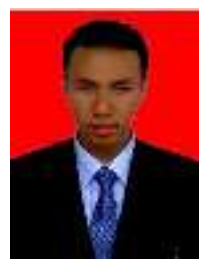

Penulis adalah mahasiswa S1 Ilmu Komputer Institut Pertanian Bogor (IPB)

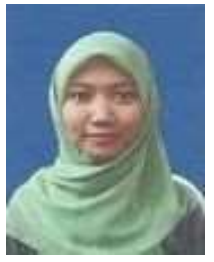

Penulis adalah mahasiswa S1 Ilmu Komputer Institut Pertanian Bogor (IPB)

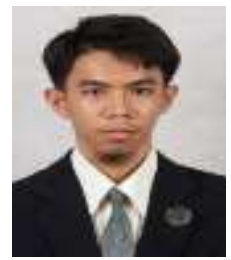

Penulis adalah pengajar di Departemen Ilmu Komputer Institut Pertanian Bogor (IPB). Selain itu, penulis juga bergabung di Bioinformatics Working Group, FMIPA IPB 